\title{
P12 - Comadronas guatemaltecas del Siglo XXI: entre Ong's y el Estado
}

\section{Guatemalan midwives of the XXI Century: between Ong's and the State}

\author{
María Fernanda Rodríguez Rivera*, María Teresa Mosquera \\ Universidad Nacional Autónoma de México -UNAM, México* \\ ${ }^{2}$ Instituto de Estudios Interétnicos-USAC \\ *Autor para correspondencia. \\ Correo electrónico: fer_bhppy@hotmail.com
}

Resumen

— $\mathrm{n}$ la ponencia se busca exponer cuáles son los elementos que determinaron la articulación entre la sociedad civil durante el _ ralelamente, hago énfasis en tres aspectos que se consideran importantes para la investigación histórica: 1) la necesidad de estudiar sujetos que no han sido analizados como actores políticos, en este caso las comadronas; 2) la vinculación de la historia con otras disciplinas como la sociología política, y 3) la importancia del trabajo con documentos visuales y audiovisuales. Considerando las múltiples tensiones que existen, analizo algunas de las alianzas y rupturas realizadas entre los diferentes actores de la sociedad civil (comadronas, universidades, ONG'S, etc.) durante las primeras décadas del siglo XXI. Se concluye que se ha generado un aumento de su participación política a diferentes escalas, lo cual repercute en la manera de acordar alianzas y establecer vínculos con la sociedad política. Para desarrollar el trabajo, se ha apoyado en la metodología propuesta por el LAIS para la investigación social con documentos visuales y audiovisuales. Teóricamente, se retoman los trabajos sobre el Estado y la democracia de Evelina Dagnino y Lucio Oliver, así como los de la Estructura de Oportunidades Políticas y de los Nuevos Movimientos Sociales de Touraine, Melucci y Tarrow.

Palabras clave: comadronas, movimientos sociales, políticas públicas, ONG's

\begin{abstract}
$\mathrm{I}^{\mathrm{n}}$ $\mathrm{n}$ the paper I seek to explain what are the elements that determined the articulation between civil society during the process of creation and approval of the National Policy of Midwives of the Four Peoples of Guatemala 2015-2025. At the same time, I emphasize three aspects that I consider important for historical research: 1) the need to study subjects who have not been analyzed as political actors, in this case midwives; 2) the linking of history with other disciplines such as political sociology, and 3) the importance of working with visual and audiovisual documents. Considering the multiple tensions that exist, I analyze some of the alliances and ruptures made between the different actors of civil society (midwives, universities, NGOs, etc.) during the first decades of the 21 st century. I conclude that there has been an increase in their political participation at different scales, which has an impact on the way to agree on alliances and establish links with the political society. To develop my work, I have relied on the methodology proposed by the LAIS for social research with visual and audiovisual documents. Theoretically, I return to the works on the State and the democracy of Evelina Dagnino and Lucio Oliver, as well as those of the Structure of Political Opportunities and of the New Social Movements of Touraine, Melucci and Tarrow.
\end{abstract}

Keywords: midwives, social movements, public policies, NGOs 


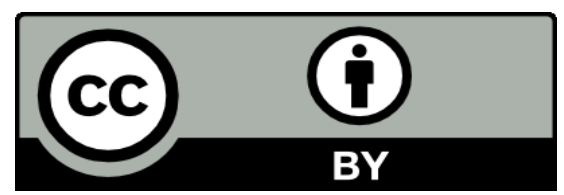

Este texto está protegido por una licencia CreativeCommons 4.0.

Usted es libre para compartir, copiar y redistribuir el material en cualquier medio o formato y adaptar el documento, remezclar, transformar y crear a partir del material para cualquier propósito, incluso comercialmente, siempre que cumpla la condición de atribución: usted debe reconocer el crédito de una obra de manera adecuada, proporcionar un enlace a la licencia, e indicar si se han realizado cambios. Puede hacerlo en cualquier forma razonable, pero no de forma tal que sugiera que tiene el apoyo del licenciante o lo recibe por el uso que hace. 